\title{
Yann Mortelette, Le Parnasse
}

\section{Maria Emanuela Raffi}

\section{OpenEdition}

\section{Journals}

\section{Edizione digitale}

URL: http://journals.openedition.org/studifrancesi/9310

DOI: 10.4000/studifrancesi.9310

ISSN: 2421-5856

\section{Editore}

Rosenberg \& Sellier

\section{Edizione cartacea}

Data di pubblicazione: 1 juin 2008

Paginazione: 216

ISSN: 0039-2944

\section{Notizia bibliografica digitale}

Maria Emanuela Raffi, «Yann Mortelette, Le Parnasse», Studi Francesi [Online], 154 (LII | I) | 2008, online dal 30 novembre 2015, consultato il 12 janvier 2021. URL: http://journals.openedition.org/ studifrancesi/9310 ; DOI: https://doi.org/10.4000/studifrancesi.9310

Questo documento è stato generato automaticamente il 12 janvier 2021.

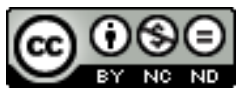

Studi Francesi è distribuita con Licenza Creative Commons Attribuzione - Non commerciale - Non opere derivate 4.0 Internazionale. 


\title{
Yann Mortelette, Le Parnasse
}

\author{
Maria Emanuela Raffi
}

\section{NOTIZIA}

yANN MORTELETTE, Le Parnasse, Paris, Presses de l'Université Paris-Sorbonne, 2006

(«Mémoire de la critique»), pp. 435.

1 In questa raccolta di scritti critici sulla scuola parnassiana, che si snodano dal 1866 (Les poétereaux di Pierre Denis) al 1925 (La réaction parnassienne et le renouveau de la phantaisie di John Charpentier) e in cui figurano molti nomi illustri di scrittori e di critici, Yann Mortelette propone una sorta di ritratto teorico del movimento, costruito dall'esterno, attraverso letture ed interpretazioni. Come si legge nell'ampia «Préface» che precede la ricca antologia di scritti, il Parnasse non ha avuto un Manifesto né una dichiarazione esplicita di poetica, ma ha costituito piuttosto un intreccio di posizioni estetiche, e talora anche politiche e sociali, che sono state quasi sempre definite in relazione a qualcosa d'altro - il romanticismo, il realismo, il simbolismo, ecc. - ma non a partire da una poetica propria. Non stupisce quindi che lo sforzo di dare una descrizione e una definizione della scuola parnassiana trovi un percorso privilegiato nella raccolta degli scritti critici sull'argomento che, proprio nella loro varietà, riescono a stringere più da vicino quello che l'autore definisce «un mouvement de transition [...] à la croisée des grands courants du siècle romantique» delle quali rappresenta «un point d'équilibre», associando insieme «harmonieusement le fond et la forme». 